ISSN $0258-7122$

Bangladesh J. Agril. Res. 32(3) : 349-357, September 2007

\title{
PRODUCTIVITY AND PROFITABILITY OF BILATIDHONIA INTERCROPPED WITH CUCURBIT VEGETABLES
}

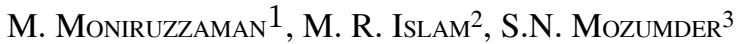 \\ S.M. M. RAHMAN ${ }^{4}$ AND N. C. DAS ${ }^{5}$
}

\begin{abstract}
The experiment was conducted to find out a suitable intercrop combination of Bilatidhonia and winter pumpkin relayed with different summer cucurbits (Bilatidhonia + winter pumpkin)/summer cucurbits) in the hill valley of the Agricultural Research Station (ARS), Raikhali, Rangamati during 2003-04 and 2004-05. The results revealed that all the intercrop combinations gave the highest fresh yield of Bilatidhonia than that of the sole Bilatidhonia with an exception of Bilatidhonia + winter pumpkin followed by ash gourd and summer pumpkin combination. Maximum fresh yield of Bilatidhonia (50.13 t/ha) was recorded from Bilatidhonia + winter pumpkin closely followed by ribbed gourd and bitter gourd (50.00 t/ha) combination which showed 15$15.5 \%$ higher than that of sole Bilatidhona. Summer cucurbits relayed with Bilatidhonia after harvesting of winter pumpkin gave reasonable good yield where ribbed gourd produced the highest yield (15.29 t/ha). Winter pumpkin intercropped with Bilatidhonia also produced reasonable good yield ranging from 31.88 to $32.68 \mathrm{t} /$ ha compared to the sole winter pumpkin. The highest Bilatidhonia equivalent (69.02 t/ha) and gross return (Tk. 10,35,35,440/ha) were obtained from (Bilatidhonia + winter pumpkin)/ bitter gourd or ribbed gourd combination. But intercropped Bilatidhonia with winter pumpkin relayed by ribbed gourd gave the highest gross margin (Tk. 859, 566/ha) with maximum benefit-cost ratio (4.90) at hilly area of Raikhali, Rangamati.
\end{abstract}

Key Words: Productivity, profitability, Bilatidhonia, cucurbits.

\section{Introduction}

Intercropping is widely practiced by the farmers in the tropics, because of increased productivity and reliability in production. Moreover, intercropping gives a greater stability of yield over monoculture (Willey and Reddy, 1981). Besides, it often provides higher cash return than growing one crop alone (Grimes et al., 1983 and Kurata, 1986) and ensures greater resource use efficiency (Pathick and Malla, 1979). Bilatidhonia (Eryngium foetidum L.) is a

\footnotetext{
${ }^{1}$ Senior Scientific Officer (Horticulture), ARS, Raikhali, Chandraghona, Rangamati Hill District-4531, ${ }^{2}$ Scientific Officer (Soil Science), ARS, Raikhali Chandraghona, Rangamati Hill District-4531, ${ }^{3}$ Senior Scientific Officer (Horticulture), HARS, Ramgarh, Khagrachhari Hill District, ${ }^{4}$ Scientific Officer, Fruit Section, HRC, BARI, Joydebpur, Gazipur, ${ }^{5}$ Senior Scientific Officer (Agronomy), OFRD, Mymensingh, Bangladesh
} 
long duration crop that requires about 250-260 days for complete harvest if sown in October or November. It is a shade-loving crop, which is generally cultivated under shade created by giving trellis over the crop (Islam et al., 2003). The crop performed well in those places where 50-75\% PAR (Photosynthetically active radiation) i.e. incident light is available (Moniruzzaman, 2004). Trellies are generally made by dhaincha stalk or coconut leaves or sun grass or rice straw, etc. with the help of bamboo sticks (Anon., 2000; Anon., 2001). Generally, the space of trellis is kept free during growing season of the crop. This free space can be utilized by growing short duration creeper type vegetables with Bilatidhonia. Cucurbits can easily be grown on the trellis as they are creeping and climbing types of vegetables. However, cucurbits grown on trellis create favourable environment for the crop as Bilatidhonia is a shade bearing crop. In this context, the present investigation was undertaken to find out the productivity and profitability of Bilatidhonia -winter pumpkin intercropping system relayed with summer cucurbits in different combinations in the hilly region.

\section{Materials and Method}

The experiment was conducted at the Agricultural Research Station (ARS), Raikhali in the district of Rangamati during two consecutive years of 2003-04 and 2004-05. The soil of the experimental plot was sandy clay loam having $\mathrm{pH}$ of 5.7. The total rainfall of 2004-05 was more than that of 2003-04. From November to February, there was no rainfall during both the years (Fig. 1). The experiment was laid out in randomized complete clock design with 3 replications. The unit plot size was $3.0 \mathrm{~m} \times 3.8 \mathrm{~m}$ consisting of 3 small plots, each measuring $3 \mathrm{~m} \times 1 \mathrm{~m}$ with $40 \mathrm{~cm}$ distance between two small plots. The unit plot was subdivided into small plots for easy preparation of plot to get good tilth of soil like vegetable seedbed that provided better germination of seeds. It was also done for better cultural management as well as for the convenience of irrigation and drainage of excess water. Seven different intercrop combinations, such as $\mathrm{T}_{1}=($ Bilatidhonia + winter pumpkin/ash gourd $), \mathrm{T}_{2}=($ Bilatidhonia + winter pumpkin/bitter gourd), $\mathrm{T}_{3}=$ (Bilatidhonia + winter pumpkin/ribbed gourd $), \mathrm{T}_{4}=($ Bilatidhonia + winter pumpkin/snake gourd $), \mathrm{T}_{5}=($ Bilatidhonia + winter pumpkin/summer pumpkin), and $\mathrm{T}_{6}=$ Sole Bilatidhonia and $\mathrm{T}_{7}=$ Sole winter pumpkin were taken in this study. Seeds of Bilatidhonia were broadcasted @ $40 \mathrm{~kg} / \mathrm{ha}$ (Anon., 2001) on finely prepared bed on 7 November and 10 in 2003 and 2004, respectively. Four holes were made to sow local 


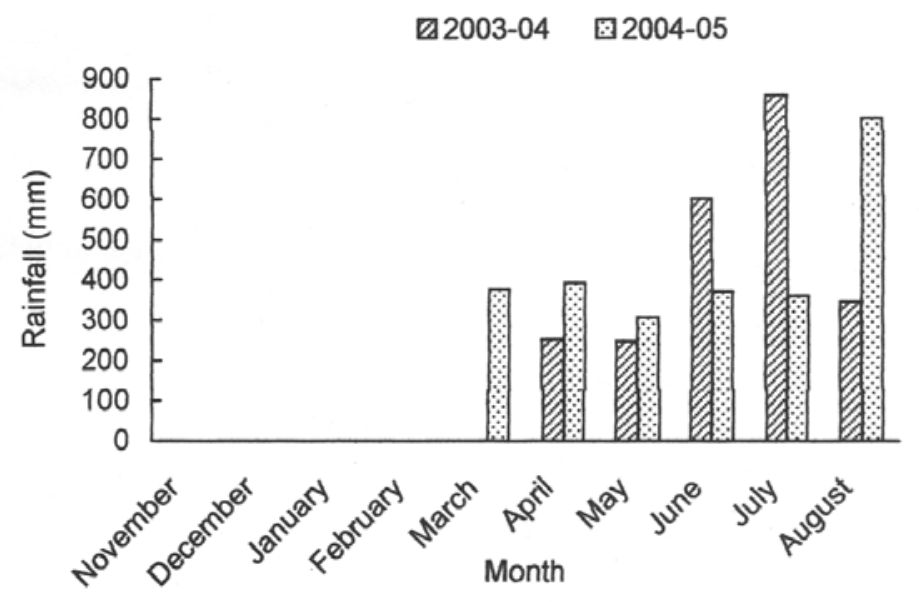

Fig. 1. Rainfall data during experimentation.

winter pumpkin seeds at every corner of the Bilatidhonia plot $(3.0 \mathrm{~m} \mathrm{x} 3.8 \mathrm{~m})$ and 6 seeds were dibbled per hole on the same date of Bilatidhonia sowing. After 15 days of dibbling, four seedlings are allowed to grow. Seeds of different local cultivars of summer cucurbits (ash gourd, bitter gourd, ribbed gourd, snake gourd and summer pumpkin) were sown into the same pit of winter pumpkin following the same principles at the last week of March after the harvest of winter pumpkin. Bilatidhonia sole crop was fertilized @ 10 tons cowdung/ha and 160-70-100 kg of $\mathrm{N}, \mathrm{P}_{2} \mathrm{O}_{5}$ and $\mathrm{K}_{2} \mathrm{O} /$ ha, respectively. $\mathrm{N}, \mathrm{P}_{2} \mathrm{O}_{5}$ and $\mathrm{K}_{2} \mathrm{O}$ were used in the form of urea, triple supper phosphate (TSP) and muriate of potash (MP). Full dose of cowdung, TSP and MP and $1 / 4 \mathrm{~N}$ were applied to Bilatidhonia during land preparation. The remaining $\mathrm{N}$ was applied in 8 equal splits at 50,75, 100, 125, 175, 200, 225 and 250 days after sowing (DAS). Water was given to the plot by water can at every 3 days for germination of Bilatidhonia seeds. Winter pumpkin sole crop was also fertilized with@5 tons of cowdung and 7060-50 kg N, $\mathrm{P}_{2} \mathrm{O}_{5}$ and $\mathrm{K}_{2} \mathrm{O} /$ ha, respectively. For sole winter pumpkin, TSP, MP and $1 / 3 \mathrm{~N}$ were applied in pits and $2 / 3 \mathrm{~N}$ was applied as top dressing at 25 and 40 DAS in 2 equal splits. For intercrop, winter pumpkin, 2.5 tons of cowdung, 35$30-25 \mathrm{~kg} \mathrm{~N}-\mathrm{P}_{2} \mathrm{O}_{5}-\mathrm{K}_{2} \mathrm{O} / \mathrm{ha}$ were used in the pits and the application method of fertilizer was as that of sole crop. For summer cucurbits, no additional fertilizers were used. Winter pumpkin sole crop was not given trellis and allowed to grow on the ground as normal cultivation followed by the hilly farmers. Winter pumpkins were allowed to climb on the trellis previously given over the Bilatidhonia crop and summer cucurbits were allowed to creep upto the same trellis with bamboo sticks. Weeding was performed as required by the crop. 
Bilatidhonia was harvested from 04 February (90 DAS) to 30 July at an interval of 25 days, winter pumpkin was harvested from January to 15 March in each year. Harvests of summer cucurbits were started on 10 June and continued upto 31 July. The yield attributes of Bilatidhonia, such as plant height, number of leaves per plant, leaf size (leaf length and leaf breadth), fresh weight of plant were collected from 10 randomly collected plants in each of 8 harvests. Each and every data on yield attributes were the average of 8 harvests. The total fresh yield was calculated from the summation of 8 harvests from all the plots. Bilatidhonia equivalent yield and economic analyses were done on hectare basis considering the market price of each crop by the following formula:

$$
\text { Bilatidhonia equivalent yield }=\mathrm{Y}_{\mathrm{BDh}}+\frac{\mathrm{Y}_{\mathrm{i}} \mathrm{P}_{\mathrm{i}}}{\mathrm{P}_{\mathrm{BDh}}}
$$

Where, $Y_{\mathrm{BDh}}=$ yield of Bilatidhonia, $\mathrm{Y}_{\mathrm{i}}=$ yield of intercrop, $\mathrm{P}_{\mathrm{i}}=$ selling price of intercrop and $\mathrm{P}_{\mathrm{BDh}}=$ selling price of Bilatidhonia.

\section{Results and Discussion}

\section{Yield and yield attributes of Bilatidhonia}

Plant height, number of leaves per plant, length of leaf, fresh weight per plant and fresh yield of Bilatidhonia were significantly influenced by different crop combinations with an exception of width of leaf and number of plants per $\mathrm{m}^{-2}$ (Table 1). Significantly maximum plant height $(22.85 \mathrm{~cm}$ and $21.46 \mathrm{~cm} 2003-04$ and 2004-05, respectively) was recorded from $\mathrm{T}_{2}$ treatment closely followed by $\mathrm{T}_{3}$ treatment in both the years and the lowest plant height was obtained from $\mathrm{T}_{6}$ treatment (Bilatidhonia sole) both years. Similar trend was also observed in respect of number of leaves per plant. The $T_{2}$ treatment significantly produced maximum number of leaves per plant (7.57 in 2003-04 and 7.16 in 2004-05), which was at par with $\mathrm{T}_{3}$ treatment (7.47 in 2003-04 and 7.10 in 2004-05). There was no significant difference among $\mathrm{T}_{1}, \mathrm{~T}_{4}, \mathrm{~T}_{5}$, and $\mathrm{T}_{6}$ treatments in both the years in respect of number of leaves per plant. Significantly maximum leaf length was obtained from $T_{2}$ and $T_{3}$ treatments followed by $T_{4}$ treatment. The minimum leaf length was recorded from $\mathrm{T}_{6}$ treatment, but there was no significant difference among $\mathrm{T}_{1}, \mathrm{~T}_{5}$, and $\mathrm{T}_{6}$ treatments in both the years. Although leaf width was not significantly influenced in both the years, the $T_{3}$ and $\mathrm{T}_{4}$ treatments produced apparently the highest leaf width in 2003-04, while $\mathrm{T}_{3}$ treatment produced similar effect in 2004-05. Number of plants per $/ \mathrm{m}^{-2}$ was more in 2003-04 than in 2004-05. 


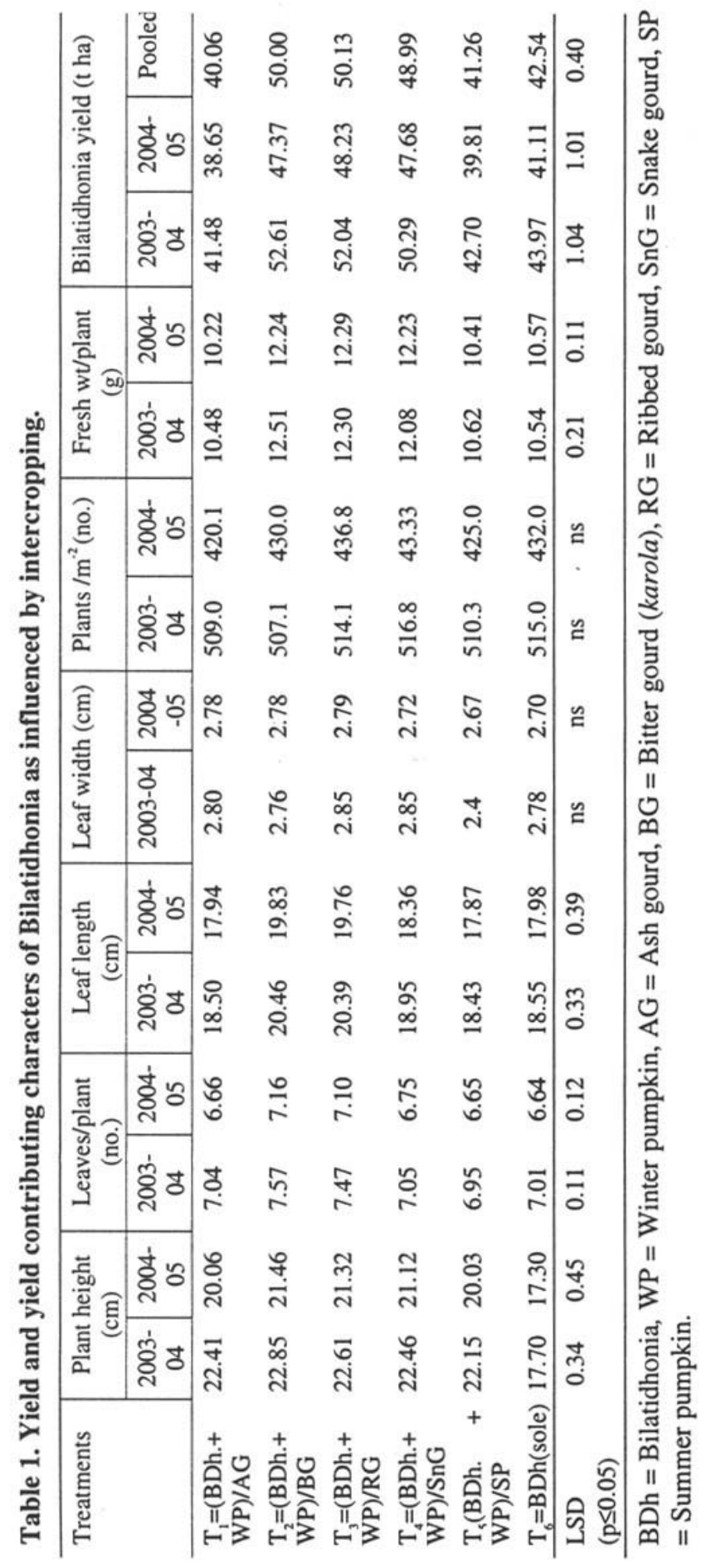


In 2003-04, maximum fresh weight per plant was found from $\mathrm{T}_{2}(12.51 \mathrm{~g})$ closely followed by $\mathrm{T}_{3}(12.30 \mathrm{~g})$ treatment with no significant difference between them. There was also no significant difference among $T_{1}, T_{5}$ and $T_{6}$ treatments in terms of fresh weight per plant in 2003-04. In 2004-05, significantly maximum fresh weight per plant was obtained from $\mathrm{T}_{3}$ treatment $(12.29 \mathrm{~g})$ closely followed by $\mathrm{T}_{2}$ and $\mathrm{T}_{4}$ treatments and the lowest from $\mathrm{T}_{1}$ treatment $(10.22 \mathrm{~g})$.

In 2003-04 significantly maximum fresh yield of Bilatidhonia was found from $\mathrm{T}_{2}(52.61 \mathrm{t} / \mathrm{ha})$ closely followed by $\mathrm{T}_{3}(52.04 \mathrm{t} / \mathrm{ha})$ and the lowest yield from $\mathrm{T}_{1}\left(41.84 \mathrm{t} / \mathrm{ha}\right.$ ) whereas in 2004-05, the highest yield was recorded from $\mathrm{T}_{3}$ (48.23 t/ha) which was at par with $\mathrm{T}_{2}(47.37 \mathrm{t} / \mathrm{ha})$ and $\mathrm{T}_{4}$ and the lowest fresh yield was found from $\mathrm{T}_{1}$ combination. Yield of Bilatidhonia varied in two years due higher number of plant population in 2003-04 than in 2004-05 in all treatment combinations. Maximum values in intercropping situation of $T_{2}$ and $T_{3}$ treatments might be the cause of creating suitable shade condition by bitter gourd and ribbed gourd for Bilatidhonia. In terms of the characters discussed above, the remaining intercropping combinations showed similar influence of $\mathrm{T}_{6}$ (Bilatidhonia sole). Only $\mathrm{T}_{1}$ and $\mathrm{T}_{5}$ treatments gave lower yield than Bilatidhonia sole.

In pooled data (Table 2), it showed that treatment $T_{3}$ and $T_{2}$ were statistically identical and they gave higher fresh yield than other treatments. Yield of Bilatidhonia was reduced considerably when ash gourd and summer pumpkin were sown as intercrops as well as relay crops.

Table 2. Yields of Bilatidhonia, winter pumpkin, summer cucurbits, Bilatidhonia equivalent yield of sole and intercropping combinations (pooled).

\begin{tabular}{l|c|c|c|c}
\hline Treatments & $\begin{array}{c}\text { Bilatidhonia } \\
\text { yield (t/ha) }\end{array}$ & $\begin{array}{c}\text { Summer } \\
\text { cucurbit } \\
\text { yields }(\mathrm{t} / \mathrm{ha})\end{array}$ & $\begin{array}{c}\text { Winter } \\
\text { pumpkin yield } \\
\mathrm{t} / \mathrm{ha})\end{array}$ & $\begin{array}{c}\text { Bilatidhonia } \\
\text { equivalent } \\
\text { yield (t/ha) }\end{array}$ \\
\hline $\mathrm{T}_{1}=(\mathrm{BDh} .+\mathrm{WP}) / \mathrm{AG}$ & 40.06 & 10.23 & 32.68 & 52.17 \\
$\mathrm{~T}_{2}=(\mathrm{BDh} .+\mathrm{WP}) / \mathrm{BG}$ & 50.00 & 13.16 & 31.88 & 69.02 \\
$\mathrm{~T}_{3}=(\mathrm{BDh} .+\mathrm{WP}) / \mathrm{RG}$ & 50.13 & 15.29 & 32.48 & 68.78 \\
$\mathrm{~T}_{4}=(\mathrm{BDh} .+\mathrm{WP}) / \mathrm{SnG}$ & 48.99 & 12.03 & 32.27 & 63.88 \\
$\mathrm{~T}_{5}=(\mathrm{BDh} .+\mathrm{WP}) / \mathrm{SP}$ & 41.26 & 11.25 & 31.88 & 54.15 \\
$\mathrm{~T}_{6}=\mathrm{BDh}($ sole $)$ & 42.54 & - & - & 42.34 \\
$\mathrm{~T}_{7}=\mathrm{WP}(\mathrm{sole})$ & - & - & 32.64 & 8.98 \\
\hline LSD $(\mathrm{p} \leq 0.05)$ & 0.40 & 0.29 & 0.60 & 0.63 \\
\hline
\end{tabular}

$\mathrm{BDh}=$ Bilatidhonia, $\mathrm{Wp}=$ Winter pumpkin, $\mathrm{AG}=$ Ash gourd, $\mathrm{BG}=$ Bitter gourd (karola), $\mathrm{RG}=$ Ribbed gourd, $\mathrm{SnG}=$ Snake gourd, $\mathrm{SP}=$ Summer pumpkin . 


\section{Yield of summer cucurbits}

Five different summer cucurbit vegetables (Ash gourd, bitter gourd, ribbed gourd, snake gourd, and summer pumpkin) were grown with Bilatidhonia after harvesting of winter pumpkin. Among cucurbits, significantly the highest yield was obtained form ribbed gourd when intercropped with Bilatidhonia (Table 2). The lowest yield of summer cucurbit was obtained from ash gourd. The yield variation among different summer cucurbits was due to the reason of bearing habit and genetic yield potentiality.

\section{Yield of winter pumpkin}

Pumpkin yield was not significantly influenced among treatments $\mathrm{T}_{1}, \mathrm{~T}_{7}, \mathrm{~T}_{4}$, and $\mathrm{T}_{3}$ but slightly lower yield was recorded in $\mathrm{T}_{2}$ and $\mathrm{T}_{5}$ (Table 2 ). It was noted that pumpkin yield was not reduced when intercropped with Bilatidhonia rather it was similar or increased in some cases.

\section{Bilatidhonia equivalent yield}

All the intercropping combinations significantly showed higher equivalent yields than those of sole crops of Bilatidhonia and winter pumpkin (Table 2). Maximum Bilatidhonia equivalent yield was obtained from $\mathrm{T}_{2}$ treatment $(69.02$ $\mathrm{t} / \mathrm{ha})$ followed by $\mathrm{T}_{3}$ treatment $(68.78 \mathrm{t} / \mathrm{ha})$ with no significant difference between the treatments. The lowest Bilatidhonia equivalent yield was found from sole winter pumpkin. The equivalent yield variations of cucurbits and Bilatidhonia were due to their yield potentiality and economic values.

\section{Cost return analysis}

The economic performance of Bilatidhonia with winter pumpkin and summer cucurbits in different intercropping combinations are presented in Table 3. All the intercropping combinations showed higher monetary return than that of sole cropping. Average of the two years' results revealed the highest gross return of Tk. 10, 35, 440/ha in (Bilatidhonia + winter pumpkin)/bitter gourd crop combination followed by (Bilatidhonia + winter pumpkin)/ribbed gourd crop combination (Tk. 10, 34, 770/ha). Ash gourd, snake gourd, and summer pumpkin did not perform well as compared to bitter gourd and ribbed gourd in association with Bilatidhonia + winter pumpkin, but recorded higher gross margin than those of the sole Bilatidhonia and winter pumpkin. In intercropping situation, it was observed that cost of production was fluctuated among different treatment combinations due to different prices of various inputs. The highest cost of cultivation was involved in (Bilatidhonia + winter pumpkin)/bitter gourd (Tk. 177, 988/ha) followed by (Bilatidhonia + winter pumpkin)/ribbed gourd 
Table 3. Cost and return analysis of sole and intercropping combinations of Bilatidhonia with cucurbits (Average of two years).

\begin{tabular}{l|l|l|l|l}
\hline Treatments & $\begin{array}{l}\text { Gross return } \\
\text { ('0000' Tk./ha) }\end{array}$ & $\begin{array}{l}\text { Total variable } \\
\text { cost ('000' } \\
\text { Tk./ha) }\end{array}$ & $\begin{array}{l}\text { Gross margin } \\
\text { ('000' Tk./ha) }\end{array}$ & $\begin{array}{l}\text { Benefit-cost } \\
\text { ratio (BCR) }\end{array}$ \\
\hline (BDh.+WP)/AG & 782.77 & 174.244 & 60.8 .526 & 4.49 \\
$(\mathrm{BDh} .+\mathrm{WP}) / \mathrm{BG}$ & 1035.44 & 177.988 & 857.452 & 5.81 \\
$(\mathrm{BDh} .+\mathrm{WP}) / \mathrm{RG}$ & 1034.77 & 175.204 & 859.566 & 5.90 \\
$(\mathrm{BDh} .+\mathrm{WP}) / \mathrm{SnG}$ & 960.17 & 164.643 & 795.527 & 5.83 \\
$(\mathrm{BDh} .+\mathrm{WP}) / \mathrm{SP}$ & 814.02 & 169.203 & 644.817 & 4.81 \\
$\mathrm{BDh}($ sole) & 638.10 & 160.244 & 477.856 & 3.98 \\
$\mathrm{WP}($ sole $)$ & 130.56 & 50.000 & 80.56 & 2.61 \\
\hline
\end{tabular}

$\mathrm{BDh}=$ Bilatidhonia, $\mathrm{Wp}=$ Winter pumpkin, $\mathrm{AG}=\mathrm{Ash}$ gourd, $\mathrm{BG}=$ Bitter gourd (karola), $\mathrm{RG}=$ Ribbed gourd, $\mathrm{SnG}=$ Snake gourd, $\mathrm{SP}=$ Summer pumpkin.

$\begin{array}{ll}\text { Crop } & \text { Rate }(\mathrm{Tk} . / \mathrm{kg}) \\ \text { Bilatidhonia } & 15.00 \\ \text { Ash gourd } & 5.00 \\ \text { Bitter gourd } & 12.00 \\ \text { Ribbed gourd } & 10.00 \\ \text { Snake gourd } & 8.00 \\ \text { Summer pumpkin } & 6.00 \\ \text { Winter pumpkin } & 4.00\end{array}$

(Tk. 175, 204/ha) and ash gourd (Tk. 174, 244/ha) combination and the lowest from both the sole crops. Similar trend was observed in the case of gross margin. The highest gross margin was obtained from (Bilatidhonia + winter pumpkin)/bitter gourd (Tk. 859, 566/ha). All the intercropping combinations showed higher gross margin than the sole Bilatidhonia and winter pumpkin. Maximum benefit-cost ratio (BCR) was obtained from (Bilatidhonia + winter pumpkin)/ribbed gourd (5.90) combination followed by (Bilatidhonia + winter pumpkin)/snake gourd (5.83) and (Bilatidhonia + winter pumpkin)/bitter gourd (5.81).

Therefore, the hilly farmers should be motivated and encouraged to grow Bilatidhonia as an intercrop with winter pumpkin relayed with ribbed gourd or bitter gourd or snake gourd instead of growing Bilatidhonia as a sole crop.

\section{References}

Anonymous. 2001. BARI Annual Report for 2000-01. Bangladesh Agricultural Research Institute (BARI), Joydebpur, Gazipur. p. 307.

Anonymous. 2000. BARI Annual Report for 1999-2000. Bangladesh Agricultural Research Institute (BARI), Joydebpur, Gazipur. p. 319. 
Grimes, A., A., M. Quasem, M. S. Uddin, N. Jahiruddin, and R. N. Mallik. 1983. The performance of different cropping patterns in 1992-1993 at the cropping system research site. Hathazari, Chittagong, RARS, publication No. 1.

Islam, M. R., S. M. Mozumder, M. Moniruzzaman and S. N. Alam. 2003. Effects of N, $\mathrm{P}, \mathrm{K}$ on yield and profitability of Bilatidhonia in the hilly region. Bangladesh $J$. Agril. Res. 28(1): 105-110.

Kurata, T. 1986. A study on the farming system in USA. Quarterly J. Agro Econ. 26(3): 179-205.

Moniruzzaman, M. 2004. Effects of light intensity and nitrogen levels on the yield and quality of Bangladhonia (Eryngium foetidum L.). MS Thesis, Department of Horticulture, BSMRAU (Bangabandhu Sheikh Mujibur Rahman Agricultural University), Gazipur, Bangladesh. p. 82.

Pathick, D. C. and M. L. Malla. 1979. Study on the performance of crop legume under monoculture and intercrop combination. Sixth Annual Maize Development Workshop, 23 May, Nepal. 1979.

Willey, R. W. and M. S. Reddy. 1981. A field technique for seperating above and below ground interaction for intercropping of expt. with pearl millet/groundnut. Expt. Agric. 17: 257-264. 